\title{
A Balto-Finnic semantic field in motion
}

Semantic and structural aspects of language contact

This study is a structural and semantic analysis of Karelian and Vepsian verbs of motion formed on the basis of borrowed Russian stems. In the course of the analysis attention is first focused on the use and distribution of Russian prefixes, as well as on the preference of all dialects for one particular Russian root, viz idti. Particular emphasis is put on the distribution of these forms across the Karelian-Vepsian geographical region. Secondly, the analysis examines the adaptation of these forms to the native Balto-Finnic morphology, and the apparent participation of the new verbs in qualitative consonant gradation. This study sheds light on the concrete effects of language contact and on the shifts that are taking place in the native system.

1. Among the large number of Russian verbs that are assimilated by Balto-Finnic dialects, the prefixed verbs of motion are particularly worthy of close attention. Earlier studies devoted to this subject have concentrated primarily on the choice of prefix in three Karelian dialects (Kalinin, Tixvin, Olonets) and in the Veps language (Pugh 1989 and 1988/89, resp.). The present study goes beyond the scope of those analyses in several ways. First, data are included from two more Karelian dialects heretofore not considered, Ludic and Valdai; all major Karelian dialects (and Veps) are now considered, allowing us to pay special attention to the role of the geographical contiguity of these dialects in the spread of the borrowed linguistic forms. Second, the attested prefixes are 
now considered not only in terms of absolute numbers, but also in relation to the total number of prefixes in each dialect (i. e., as percentages of the whole). Finally, although the structural adaptation of these verb forms to the Balto-Finnic system has been alluded to in previous studies, here we examine the structural anatomy of their assimilation in great detail. ${ }^{1}$

In the following discussion the borrowed verbs in question are analyzed from left to right, beginning with the prefix, followed by the stem, and finally ending with a discussion of some of the morphological markers of person, number, and tense. This order is somewhat arbitrarily chosen as the one best suited to a systematic treatment of their structural makeup.

2.0. The enumeration of attested prefixed forms (see table 1) is presented in relation to the geographic distribution of the dialects in question, moving from the Olonets dialect in the NW to the Kalinin dialect in the SE. 2

\begin{tabular}{llllllllllll} 
& pro & u & pod & do & vi & pere za & ob & s(o) & pri & TOTALS \\
\hline Olonets & 28 & 4 & - & - & - & 1 & - & - & - & - & 33 \\
Ludic & 60 & 14 & 13 & 1 & - & 4 & - & - & - & - & 92 \\
Veps & 44 & 41 & 15 & 1 & - & - & 8 & 1 & - & - & 110 \\
Tixvin & 48 & 72 & 2 & 4 & 7 & 1 & - & 1 & - & - & 135 \\
Valdai & 15 & 27 & 3 & 2 & 10 & - & 1 & 1 & 2 & 1 & 62 \\
Kalinin & 19 & 17 & 1 & 9 & 22 & 1 & 1 & - & - & - & 70 \\
\hline & 214 & 175 & 34 & 17 & 39 & 7 & 10 & 3 & 2 & 1 & 502
\end{tabular}

Table 1

These numbers give the reader a good idea of the distribution of the prefixed verbs in question, but they do not tell the whole story. A better gauge of the importance of the individual prefixed forms is their occurrence relative to one another, that is the percentage of the total number of attestations which these forms make up in each dialect. Since the corpora of texts differ in size, such a relative consideration will also be more equitable than a strictly quantitative one. The contents of the preceding table can therefore be represented as the following percentages: 


\begin{tabular}{|c|c|c|c|c|c|c|c|c|c|c|c|c|}
\hline & pro & $\mathbf{u}$ & pod & do & vi & pere & & $\mathrm{ob}$ & & pri & & TOTALS \\
\hline Olonets & 85 & 12 & & & & 3 & & & & & : & 100 \\
\hline Ludic & 65 & 15 & 14 & 1 & & 4 & & & & & : & $99 *$ \\
\hline Veps & 40 & 37 & 14 & 1 & & & 7 & 1 & & & : & 100 \\
\hline Tixvin & 36 & 53 & 1 & 3 & 5 & 1 & & 1 & & & : & 100 \\
\hline Valdai & 25 & 44 & 5 & 3 & 16 & & 2 & 2 & 3 & 2 & : & $102^{*}$ \\
\hline Kalinin & 27 & 24 & 1 & 13 & 31 & 1 & 1 & & & & : & $98 *$ \\
\hline
\end{tabular}

Table 2

( ${ }^{*}$ Do not add up to $100 \%$ because some of the numbers were rounded up or down.)

With the possible exception of $z a$-verbs of motion in Veps and pere- in Ludic, the last five columns in the tables, i. e. with the prefixes pere-, $z a-, o b-, s(o)$-, and pri- can be statistically disregarded. If we look at the rest of the prefixes, however, we can see several clear tendencies, as depicted in table 3 (the arrows are pointed in the direction of increased attestations):

$\begin{array}{lllllll} & \text { pro } & \text { u } & \text { pod } & \text { do } & \text { vi } & \text { za } \\ \text { Ol. } & \wedge & \| & & & & \\ \text { Lu. } & \| & \| & \wedge & & & \\ \text { Ve. } & \| & \vee & \| & & & \| \\ \text { Ti. } & \| & \wedge & \| & \| & \| & \\ \text { Va. } & \| & \| & \| & \| & \| & \\ \text { Ka. } & \| & \| & & \vee & \vee & \end{array}$

Table 3

This somewhat impressionistic view of their relative distribution can also be portrayed more graphically as:

\begin{tabular}{|c|c|c|c|c|}
\hline pro & $\mathrm{u}$ & pod & do & vi \\
\hline $\operatorname{xxxxxxXX}$ & $x x$ & & & \\
\hline $\operatorname{xxxXXX}$ & $\mathbf{x x}$ & $x x x$ & & \\
\hline $\operatorname{xxxx}$ & $\operatorname{xxxxxx}$ & $x x x$ & & \\
\hline $\operatorname{xxxx}$ & $\operatorname{xxxxxx}$ & & $\mathbf{x}$ & $x$ \\
\hline $\operatorname{XXXX}$ & $\operatorname{xxxx}$ & $\mathrm{x}$ & $\mathbf{x}$ & $\mathbf{x x x}$ \\
\hline $\mathrm{XXXX}$ & $\mathrm{XXXX}$ & & $\mathbf{X X X}$ & $\mathrm{xxxx}$ \\
\hline
\end{tabular}

Table 4 
Overall, the most even distribution of the various prefixed forms is to be found in the Kalinin dialects of Karelian; on the basis of the last two diagrams, however, Tixvin and Veps appear to be the most 'active' of dialects. This is only to be expected, however, if we apply the theory of lateral areas to this situation: central regions of a dialect continuum exhibit the most changes, i. e., are most dynamic. ${ }^{3}$

2.1. A glance at the semantic component of these borrowings reveals several features, in some respects innovations, shared by all the dialects studied.

2.1.1. The motion verbs with pro- express several different kinds of movement, such as 'through', 'past', and 'across' space, as well as moving 'through' time; of these, the concept of moving 'across' space in Russian is not usually expressed by this prefix, but by pere-. The extension of the semantic component of this prefix to include this meaning may explain why Russian pere- is not widely borrowed (but cf. Ludic above). By using verbs of motion which express such distinctions by themselves, the use of various post- and prepositions such as Karelian and Veps l'äbi 'through' and Karelian pöäličči 'across', can sometimes be avoided. Examples: Valdai proidiw 'goes past', Ludic proid'ii 'passed by (time)'; sometimes a postposition can be used adverbially with one of the new verbs, indicating that the meaning of the latter may at times be more general, i. e., 'to go': cf. Valdai proidi l'äbi (Est 'läks läbi') 'went through'.4

2.1.2. Along with pro-, the most widely accepted prefix is $u$-. The general meaning of $u$-verbs is 'leaving', a fact that (as mentioned in my earlier studies) seems to signal a weakening of this meaning in the native verb läht' /läks- in favor of 'setting out', or the inception of action, roughly equivalent to one of the uses of the prefix po- in Russian. This is confirmed in a Valdai text, in which we happily find this verb used in conjunction with the borrowed verb uid'- to signal the inception of a subject's de- 
parture: lähtiettih uidimah, translated into Estonian as 'läksid minema' ('they left'). In addition, we find that $u$-verbs can express 'moving away from' in all of the dialects; this removes the need for the Balto-Finnic dialects to assimilate a verb of motion with the Russian prefix which expresses this particular meaning, i. e., the prefix ot-. Finally, in all of the Karelian and Veps dialects named above, we find that $u$-verbs of motion are also used to convey a more precise notion of going 'away from', viz. that of 'running away', 'fleeing', or 'escaping'. Although such a meaning is also contextually possible in Russian ujti, the extent to which it occurs in Balto-Finnic suggests another instance of (remarkably widespread) innovation in these dialects. Example from Ludic Karelian: ei uid'i (Fin 'ei pakene') 'does or will not escape'.

2.1.3. The prefixes pod- and do- may be treated together, since they express meanings which are quite similar, viz. 'approaching' and 'reaching'. This would suggest the possibility of a period of competition between the two prefixed verbs in the various dialects: if we look back at table 2, we see that this does in fact seem to be the case. In Ludic Karelian and Veps, it appears that pod- has become accepted, while do- is the preferred form in Kalinin Karelian. In Tixvin and Valdai Karelian, two dialects geographically situated between Ludic/Veps in the north and Kalinin in the south, neither one has become generally accepted. In Tixvin in particular, the combined attestations of the two only come to $4 \%$ of the total number of prefixed verbs of motion found; in Valdai, on the other hand, a certain need for a verb of motion expressing 'approaching' or 'reaching' is evidently felt (the two total $13 \%$ of the attested forms), but pod-and do- appear to be in a state of competition. Examples: Valdai podoidie (Est 'juurde tulla') 'to come up to, approach', Ludic podoidida (Fin 'lähestyä') 'to approach'.

2.1.4. The data obtained from Valdai and Ludic Karelian have confirmed our earlier conclusions regarding the prefix $v i-$ in 
the southern regions of Karelian proper, the adoption of $v i$ - is conditioned by the loss of a morphologically distinct elative ("out of') case in many Karelian dialects. As we move further to the north and west, from Kalinin to Valdai and Tixvin, the occurrence of Russian verbs of motion with this prefix decreases (although they are still in evidence). This is probably attributable to their relative proximity to the southern reaches of the Veps language, in which a new elative case marker (-pai, var. -päi, -pei) has developed, in the process eliminating the need for a verb to express motion 'out of'. This new elative case is also found in Ludic, a dialect that is historically derived from Veps (Virtaranta 1985: 125). The elative is still viable in Olonetsian, most likely the combined result of eastern Finnish influence and the isolation of this dialect from the southern Karelian dialects, and the prefix $v i$ - is consequently not in evidence in this dialect either. Example: Valdai viidikkoa! (Est 'tulge välja öue!') 'come/go outside!'

3.0. The structural aspect of the assimilation of these verbs has been insufficiently studied. Consequently we shall pay close attention to the inflectional side of their adaptation to the BaltoFinnic system. Before we advance to inflectional morphology, however, we must look at the root form which (with the prefix) makes up the new Karelian stem.

3.1. The Russian verb which forms the basis of the new verbs in Karelian and Veps is idti 'to go' (Russian determinate); the corresponding Russian indeterminate xodit' is found comparatively rarely. Thus, in the Ludic textes studied, the latter occurs only 3 times, compared to 93 attestations of verb forms based on $i d t i$; in the collection of Valdai texts, xodit' is only found once, while idti verbs occur a total of 61 times. 5

3.1.1. As a general rule, idti is used in the Karelian and Veps dialects to express motion in general, whether on foot or by vehicle; if motion by means of some conveyance is specifically indicated, the corresponding Finnic verb (Kar ajua, Kar/Fin ajel- 
la) is usually used. The Valdai texts show, however, that the Russian determinate verb jed- can occur in that dialect to express 'motion by vehicle'. Various prefixed forms of this verb are attested in the language of several different speakers: proijedi (Est 'sõitis läbi') 'rode past', uijedittih (Est 'sõitsid ära') 'rode away', etc.; these verb forms occur a total of 9 times. ${ }^{6}$ We also find one such case in Tixvin: ei projiedi (Rus 'ne projedet') 'will not pass through'. Given the proximity of Valdai and Tixvin Karelian, it would not be out of place to point to these verb forms as examples of a development shared by the two dialects; such a statement must, however, await evidence of wider use of the root -jed- in Tixvin Karelian.

3.1.1.1. Several apparent instances of the use of this verb are found in Veps: 6 forms of the stem proed'- 'pass through or by' are attested in two south Veps dialects. However, these can be explained as evidence of developments characteristic of the Veps vocalic system, in which the raising and lowering of vowels in certain environments (especially in diphthongs) is not unexpected. In the present instance, the diphthong [oi] experiences a lowering of the second member ( $>$ [oe]), which in effect lessens the distance between the two vowels. This turns out not to be an unusual occurrence, because we find other examples from central Veps dialects in which the first member of the same diphthong is raised for the same reason: preidi < proid' 'prošl' (passed through/ by); podeitta < podoitta 'podojti' (to approach).

3.2. From the root (or choice of Russian verb) we proceed to the stem of the new Karelian verbs. In this regard, what we expect to find and what we do in fact find are not always the same thing. Judging by the assimilation of Russian verbs in general, the stem of a new Karelian verb is based upon the non-past of the Russian verb: thus, we should expect the new Balto-Finnic verbs to be based upon a stem -id-. 
3.2.1. In Veps and Ludic Karelian (which is based on Veps) this is in fact what the stem looks like in all attested forms: Ludic oli uidinu (Fin 'oli lähtenyt') 'had left', Veps uidim (Rus 'my us'li') 'we left'. There are apparent exceptions to this rule in Veps, but again changes have taken place which are characteristic of the Veps phonological system that serve to differentiate this language from the Karelian dialects surrounding it. In this instance it is the devoicing of voiced consonants which takes place before voiceless consonants: uitkam! (Rus 'uidem!') 'let us leave!' in which $-d k->-t k$. Compare also the infinitive in Ludic vs. Veps: Ludic podoidida 'to approach', proidida 'to pass', in which stem-final $-d$ - is regularly preserved; Veps podeitta 'to approach', doitta 'to reach', proitta 'to pass through/by'. We can account for stem-final $-t$ - in the Veps forms by losing the stem-marker $-i$ - before the infinitive ending $-t a$, thereby bringing stem-final $-d$ into contact with a voiceless consonant: $-d[i]-t a>-d-+-t a>-t t a .^{7}$

3.2.2. In all of the remaining dialects studied, the situation is not so clear-cut. Although most of the finite verb forms attested occur with stem-final $-d-$, a significant number of them are found with stem-final $-j-$ :

$\begin{array}{lllll} & \text { Olonets } & \text { Tixvin } & \text { Valdai } & \text { Kalinin } \\ -d- & 15 & 89 & 52 & 42 \\ -j- & 16 & 28 & 9 & 26\end{array}$

Table 5

At first glance, we appear to be dealing with the existence of two competing stem-types; as further study of their distribution shows, however, the question is not one of competing stems. An examination of all the attested verbs in paradigm form reveals a relationship between the two sets of forms rooted in the BaltoFinnic system. In fact, this set of verbs has been assimilated to the native system to such an extent that it is witnessing consonant gradation (strong grade $d>$ weak grade $j$ ) of the type characteris- 
tic of a Karelian stem type. ${ }^{8}$ According to the Balto-Finnic system of gradation, the strong grade occurs in open syllables while the weak grade appears when the syllable is closed: this explains why $-d$-is consistently present in the infinitives in all the dialects. The lack of consonant gradation in Veps has assured the retention of stem-final $-d$ - in those dialects. In Ludic, however, the lack of a $d \sim j$ alternation has another explanation and cannot simply be attributed to the historical connections of this dialect with Veps. Although consonant gradation exists in Ludic, in Karelian in general this process involves primarily the voiceless consonants, especially $t$ and $k$ (Osnovy: 16, 45); because voiced $[d]$ has attained phonemic status in Ludic (and here it does follow Veps), this consonant has been taken out of the gradation process. ${ }^{9}$

The Karelian paradigms constructed on the basis of texts from the other dialects in question show that the attested verbs by and large conform to the Karelian system of gradation (see table 6). Despite their general conformity, however, there are instances in which the general principles of gradation are violated; the paradigms are evidently still in a state of flux. In order to evaluate them better, we shall examine the present and past paradigms by dialect.

As the following table shows, not all persons are attested; in the case of the third persons plural, the weak grade $(-j-)$ is to be expected, because the forms used in these persons are present and past impersonal forms, used in place of the historical third persons. The overrepresentation of the third singular in the texts studied merely reflects the narrative character of the latter. The number of occurrences of each form (including variants) is supplied following each ending; an asterisk marks the presence of an unexpected form, i. e. a form that violates the principles of gradation. 
PRESENT OLONETS TIXVIN VALDAI KALININ

Singular

$\begin{array}{lllllllll}1 & & & -j i n / m & 2 & -j i n & 1 & -j i n & 3 \\ 2 & j i t & 1 & & & { }^{*}-d i t & 1 & -j i t & 5 \\ 3 & *_{-j i w} & 2 & -d u(h) & 35 & -d i w & 7 & -d i w & 8\end{array}$

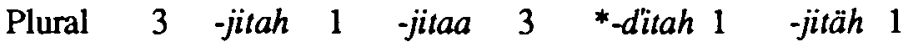

IMPERFECT

\begin{tabular}{|c|c|c|c|c|c|c|c|c|}
\hline \multirow[t]{3}{*}{ Singular } & 1 & $-j i(i) n$ & 2 & $-j i i$ & 1 & & & $-j i(i) n 6$ \\
\hline & 3 & $*_{-j i}(i)$ & 5 & $-d i$ & 38 & $-d i$ & 32 & $-d^{\prime} i(i) 29$ \\
\hline & & $-d i(i)$ & 9 & $(\varnothing$ & 1) & & & \\
\hline \multirow[t]{2}{*}{ Plural } & 1 & *-dimö & 1 & -jimma & 1 & & $*-d$ & $a 2$ \\
\hline & 3 & -jittih & 4 & $\begin{array}{l}-j i t t i i \\
\text {-ïttih }\end{array}$ & 6 & $\begin{array}{l}\text {-jittih } \\
\text { *_dittih }\end{array}$ & 5 & $-j i t t$ \\
\hline
\end{tabular}

Table 6

The classic Balto-Finnic paradigm is represented by the system found in Tixvin, in which all forms follow the expected pattern: strong grade in the 3rd singular present and past, weak grade everywhere else; cf. the Tixvin Karelian verb vedi 'he pulled/ dragged', stem vejä- (Rjagoev 1977: 131). The present tense in Kalinin is more complete, and also shows perfect adherence to the system of gradation; the past paradigm, however, reveals a violation in the 1 st plural.

The data from Valdai and Olonets indicate movement in opposite directions. In the former, we see the strong grade marker $-d$ - in forms where the weak is traditionally expected, viz. in the 2nd singular (present) and even in the impersonal 3rd plural, present as well as past. This suggests incomplete adaptation of the Valdai verbs to the Balto-Finnic system of gradation. Whether the present paradigm represents a stage on the way to complete adherence to gradational patterns, or to the extension of the strong grade $-d$ - to all persons will depend on the study of more recent data. ${ }^{10}$ Conversely, in Olonets we see an extension of the weak grade $-j$ - to forms where the strong is expected, viz. the 3rd 
singular present and past; only one occurrence of strong $-d$ - is found where it is not expected, in the 1st plural (past). Where there are violations of the principles of gradation, we would expect them to be of the kind found in Valdai Karelian; the situation in Olonets therefore requires a slight digression on the nature of the relationship between $d$ and $j$.

3.2.2.1. The geographic location of the Olonets dialect $-\mathrm{NW}$, close to Finland - may play some role in the question at hand. Throughout the Finnish dialects there are alternations not found in the literary language which point up the marginal status of $[d]$ in the Finnish phonemic system. Thus, we find in Häme $l$ for $d$ ( $k$ älet 'hands'), in South Bothnian $r$ for $d$ (tehrä 'to do'); it is not insignificant that the phonemes which occur in place of $[d]$ are sonorants. In other dialects $[j]$ may occur in place of weak grade $[d]$ : North Bothnian sota : sojasa (lit. sodassa) 'war : war-inessive'; Savo (bordering on the USSR and Karelian!) käsi : käjen! käen (lit. käden) 'hand : hand-genitive'. ${ }^{11}$ We must also take into account the fact that some northern Karelian dialects have no voiced stops, while to the east of Olonets, Ludic and Veps show complete phonemicization of $[d]>/ d /$. In short, we have data which suggest 1) that a Russian verb (or set of verbs, if we differentiate between the various prefixed forms) is assimilated to a system characterized by consonant gradation; 2) the Russian stem-final consonant $-d$ - enters into a 'gradational relationship' with $-j-; 3$ ) the marginal status of $[d]$ in that dialect then allows for a more universal replacement of $[d]$ by $[j]$. As in the case of forms with unexpected $[d]$ in Valdai, the future of this verb in particular and borrowed verbs with stem-final $-d$ - in general will depend greatly on the degree of influence Russian will exert and on the extent of Olonets-Karelian language maintenance in future years.

3.3. We now move still further to the right in our borrowed verb forms to complete the structural analysis: in this section we 
examine the presence or absence of a past tense marker $-i$ - in the paradigms of the imperfect tense. There are different processes which take place in the generation of the singular and plural past tense forms, so we shall examine the singular and plural separately.

3.3.1. The most widespread past tense marker in BaltoFinnic is $-i-.12$ The marker may also be $-\varnothing$, depending on stemtype: thus in Tixvin we can find such 3rd singular imperfect forms as harjadu 'he/she became used to' and ajo 'he/she drove (out)' (Rjagoev 1977: 130). In these forms a right-deletion rule causes the marker of the past tense $(-i-)$ to be lost in Karelian. ${ }^{13}$ The normal left-deletion pattern occurs in verbs with stem-final $-i$-, of which $3 \mathrm{sg}$ vedi (cf. above) is an example, and to which the majority of new verbs based on Russian borrowings, including the verbs of motion, adapt. ${ }^{14}$ Interaction with and reaction to this Karelian stem-type appear to be causing some fluctuation in the imperfect paradigms of the verbs based on Russian idti. In order to understand what is happening we shall take a standard Finnish verb of this type as representative of the Karelo-Finnic type (sopia 'to suit, fit', root sope-) in its present as well as its imperfect forms, and compare its endings with those of the new Karelian verbs.

Finnish

Present

$\begin{array}{ll}1 & \text { sovi-n } \\ 2 & \text { sovi-t } \\ 3 & \text { sopii }(i)\end{array}$
$\begin{array}{lll}\text { Imperfect } & 1 & \text { sovi-n } \\ & 2 & \text { sovi-t } \\ & 3 & \text { sopi- } \varnothing\end{array}$

Karelian

$\begin{array}{llllll}\text { Present } & 1 \text { (Tix) } & \text { uji-m* } & \text { Imperfect } & 1 & - \text { in } 6 \mathrm{x} ;-i i n 3 \mathrm{x} \\ & 2 \text { (Ol) } & \text { proiji-t } & & 2 & -i i D \text { (only once) } \\ & 3 \text { (Val) } & \text { proidi-w } & & 3 & -i 132 \mathrm{x} ;-i i 48 \mathrm{x}\end{array}$

Table 7

* $-n>-m$ before labials: ujim $\_$minä 'I left'. 
The present tense forms offer standard paradigms in both languages; the only difference is the treatment of the 3rd singular (long vowel in Finnish, vowel $+w$ to form a diphthong in most Karelian dialects, long vowel in Tixvin). It is the imperfect where structural problems arise, because the Finnish first and second persons are identical to those of the present: here a leftward deletion rule is in effect ensuring that certain root-vowels (here $-e-$ ) are deleted in the environment of the marker of the imperfect. Only in the third person imperfect is the ending unambiguous, a short vowel serving to differentiate it from the third person present form.

Whereas the Finnish system accepts the identity of the first and second person forms across two tenses, it is apparent that the Karelian (and as a matter of fact the Veps) do not. The absence of a past tense marker to differentiate these forms formally from the present thus tends to attract the tense marker found in other verbs in the system (i); the result is long $\bar{l}+$ personal ending. Stated another way, systemic pressure to differentiate between the forms of the two tenses causes a negation of the deletion rule in these Karelian and Veps dialects. Out of a sense of systemic symmetry, however, there is pressure for the deletion rule to be negated over the whole of the paradigm. Thus we have the third person singular redundantly marked in the imperfect: although it is already differentiated from the present by the lack of an overt person marker (e. g. present $-i-w$ but imperfect $-i-\varnothing$ ), a long $\bar{i}$ serves to even out the paradigm. In effect, however, this redundancy ensures that the number of forms attested with short $i$ outnumbers those with long $i$ in most dialects. Only in the northwesternmost dialects do we find long $i$ becoming the preferred form: in Olonets $-i i$ occurs $9 \mathrm{x},-i 5 \mathrm{x}$; in Ludic there is no competition between long and short, all 35 attested forms have long $i$. Future studies will examine the productivity of this phenomenon in assimilated Russian verbs in general which conform to this stem-type. ${ }^{15}$ 
3.3.1.1. The first person singular of the imperfect in Veps is differentiated from the first person of the present tense by the final consonant: present -in, imperfect in, where $n$ represents palatalized $n$. There is consequently no need for the verbs to adopt long $\bar{l}$ in this person. Two attested instances of $i n$ representing the first singular present are easily explained as the result of assimilation of final $-\boldsymbol{n}$ to a following palatalized consonant. The second singular is not attested in the Veps texts.

In Veps the third singular pattern is virtually identical to the one found in the majority of Karelian dialects: long $-\bar{l}$ is found $4 x$, while the preferred short $-i$ occurs $29 \mathrm{x}$. It is interesting to note that, in this respect at least, the Ludic Karelian dialect agrees with neighboring Olonets Karelian rather than with Veps; as we have seen, Ludic is usually in agreement with the closely related Veps language.

3.3.2. The entire question of the Karelian plural paradigm in the imperfect boils down to the forms of the first plural: the second is not attested, and as we saw above (table 6) the forms of the third plural are historically impersonal forms. For Veps, however, we do have morphologically distinct forms in the third person: $-i b a(3 \mathrm{x})$ and $-i b a(d)(3 \mathrm{x})$; whereas all of these are already morphologically marked for the imperfect tense (marker - $b a$ ), the latter are redundantly marked by the presence of long $i$. We can only suppose that such 'extra' marking is induced by the proximity in form of $-i b a$ to the 3rd singular present ending $-i b$.

The first plural imperfect is attested in all dialects but Valdai Karelian. We may take the same Finnish verb as above as our starting point: in that language, present sovimme is identical to imperfect sovimme; here again we find the deletion rule at work. Although this ending -imme does occur in the texts studied, the identity of the first person in both tenses is stimulating changes in its form, as was the case in the singular paradigm. One way this is happening is by the negation of the rule deleting stem- 
$i-$, as we saw in the singular. There is another mechanism at work, however, in some cases effecting a shortening of the first plural person marker - $m m->-m$ - (shortening of long - - -). This mechanism is also a deletion rule of sorts, but it is one which embraces the morphological complex as a whole, not just the vowel(s) $-i-i-$. First let us look at all the forms attested (where $\mathrm{V}$ stands for any vowel and $-i-i$ - represents long $-\bar{i}-$ ):

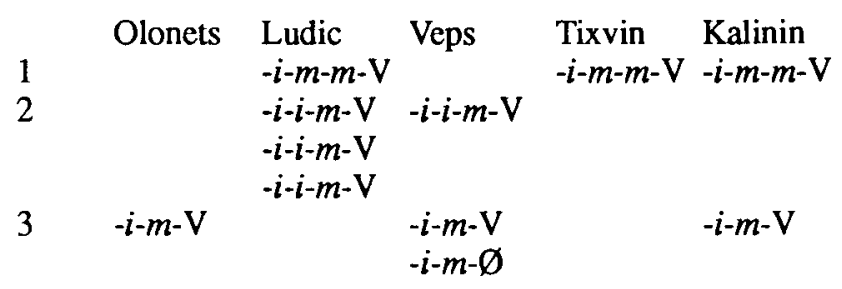

Table 8

If we examine all the forms found in our Karelian and Veps texts, and treat the stem-marker $-i$ - and tense marker $-i$ - as separate (morpho)phonemes, we can formulate a general principle which determines one mechanism of change in these dialects. Nowhere

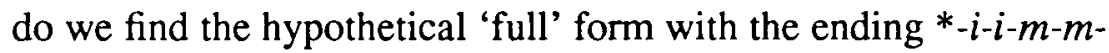
$\mathrm{V}$ : the system will not support adjacency of two - $i$-'s and long $-m$ (orthographically $-\mathrm{mm}$-) preceding the final vowel, tending instead to delete one $-i$ - or to shorten long $-m-$. In row 1 we see three attestations of the form agreeing with the standard Finnish type (sovimme), in which one $-i$ - was deleted. Row 2 reveals that undeleted $-i-i$ - may remain, as long as long $-m$ - is shortened; the end result is thus the same, one long and one short constituent. We see from row 3, however, that several of the dialects have further reduced the makeup of this morphological ending to two short constituent members, as the minimum required to differentiate the imperfect from the present: since the first plural in the present is characterized by long $-m$ - all that is needed is a shortening of this consonant. The general nature of this change is 
confirmed by a detailed analysis of all assimilated verbs (borrowed from Russian) in the collection of Kalinin Karelian texts: the majority of the forms of the first plural imperfect have reduced $*_{-}-i-i-m-m-V$ to $-i-m-V$ (Pugh 1987).

4.0. The purpose of this study has been to examine in detail one particular set of verbs assimilated by 5 Karelian dialects and Veps from various points of view, keeping in mind all the while the assimilation of these verbs in the context of the larger framework of the Karelian-Veps dialect continuum. A cursory look at data from another related language will serve to underscore the systemic nature of the assimilatory processes at work.

Geographically close to the Karelo-Veps regions we find several cases of prefixed verbs of motion in Lapp (Sámi); in this instance the examples are found in the Kildin dialect, which has been under greater Russian linguistic influence than the more western dialects. The most commonly found forms appear to occur with the Russian prefix u-: ujjte (Rus 'ujti') 'to leave', is listed along with numerous verbs derived from this base verb in Kuruč 1985 (pp. 370-71); ujtma pastex' (Rus 'ušedšij pastux') 'the shepherd (who) left' is cited in Osnovy (p. 244); one of the Lapp texts in Kert 1961 (p. 30) yields the form uide (Rus 'ušel') 'he left', which is very reminiscent of the 3rd singular imperfect forms cited above in Karelian and Veps (p. 30). Also listed in Kuruč 1985 (p. 67) is the verb vyjjte (Rus 'vyjti, ujti') 'to go out, to leave', which is of particular interest: the inessive and elative have collapsed in Lapp as they did in Karelian, the difference being that the Lapp inessive/elative case marker is often -st, i. e., the marker of the elative, rather than of the inessive as it is in Karelian.

This Karelian-Lapp morpho-semantic parallel merits further investigation; whether it should be characterized as a parallel development in the two languages or as a result of earlier KarelianLapp language contact must be the topic of a future study. As the 
Kildin data show, these prefixed Russian verbs of motion deserve further consideration, perhaps beyond the confines of BaltoFinnic, especially when their use reflects semantic or structural changes within the Balto-Finnic system. Close study of this one specific class of verbs also suggests that the analytical methods applied here ought to be extended to a study of the corpus of all prefixed Russian verbs borrowed by the Balto-Finnic languages, to confirm the general nature of these changes.

\section{Notes}

1 My thanks to Robert Austerlitz, who provided advice and assistance in the structural section of this paper.

2 The geographic position of the dialects relative to one another may be plotted on a map as follows:

OLO

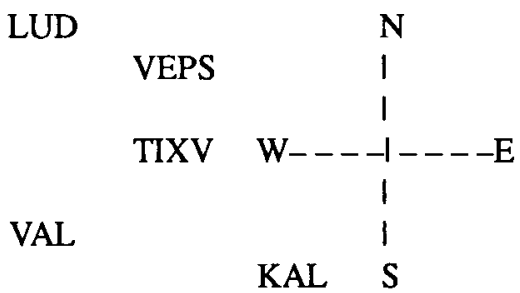

3 Here this principle is applied to a small number of dialects, i. e. on a much smaller scale than is the case elsewhere: cf. especially Korhonen 1986: 156-162.

${ }^{4}$ Examples will be cited primarily from the new dialects analyzed, i. e., Valdai and Ludic, unless examples from others are necessary for specific comparisons. The collections of texts used in the analysis of Valdai and Ludic Karelian were Palmeos 1962 and Virtaranta 1963, respectively.

5 In neither dialect, however, do the attested forms of Russian -xodit' express motion in the strict sense: in Valdai it reflects Russian poxodit' 'to resemble'; in Ludic, also prefixed with po-, this verb expresses the meaning 'to accompany'. 
6 No verb forms based on idti in this collection of texts are translated into Estonian using the verb soitma 'to go by vehicle'.

7 The loss of a final vowel (whether stem-final or absolute final) is quite frequent in Veps: cf. for example the form en doidnu 'I did not get there', with the Ludic example cited above (uidinu). On the infinitive in Veps, see Zajceva 1981: 270.

8 This possibility was alluded to in Pugh 1989.

9 Voiced stops are secondary in all Uralic languages; the protolanguage only had the voiceless stops $p t k$ (Hajdu 1985: 206).

10 One factor that will play a role in the future development of these paradigms will be the extent of language maintenance in the face of Russian influence in years to come.

11 These examples from Osnovy, e. g. pp. 137, 139.

12 The marker -si-is more common in Estonian.

${ }^{13}$ The usual direction in this type of deletion is to the left (cf. Fin sope- in 3.3.1.). At this point it seems that we can simply add the new right-deletion rule in this Karelian dialect for those environments (root in $-o$ - or $-u$-) in which there is no left-deletion: whereas in Finnish the imperfect marker is kept in such environments (cf. Fin ajoi < -ai 'he/she drove', sanoi 'he/she said', lauloi < - ai 'he/she sang'), the redundancy of this marker causes it to be lost in the Karelian dialect.

${ }^{14}$ Russian verbs in which the stem classifier is $-V j$ - (usually $-a j-$ or $-u j$-) are taken into Karelian and Veps with this stem marker: gul'aj-, torgui-, etc. Verbs of all other Russian stem-types are assimilated to the Balto-Finnic system as -i-stems, i. e., with a stem-marker -i-: roskaži-, beríi-, soglaśsi-, etc. (where only the last example is an $-i$-stem in Russian). See Pugh 1987.

15 It would be of particular interest to determine whether this is also found in verbs of native Balto-Finnic origin.

\section{References}

Hajdú, P. 1985. Ural'skie jazyki i narody. Moscow.

Kert, G. M. 1961. Obrazcy saamskoj rexi. Moscow-Leningrad.

Korhonen, M. 1986. History of the Uralic Languages and the Principle of Lateral Areas. Finnisch-Ugrische Forschungen XLVII, 2-3 (1986), pp. 156-162.

Kuru丈, R. D. 1985. Saamsko-russkij slovar'. Moscow.

Makarov, G. N. 1963. Obrazcy karel'skoj reči. Kalininskie govory. MoscowLeningrad.

and V. D. Rjagoev 1969. Obrazcy karel'skoj reci. Govory livvikovskogo dialekta karel'skogo jazyka. Leningrad. 
Osnovy finnougorskogo jazykoznanija. Pribaltijsko-finskie, saamskij i mordovskie jazyki. Moscow, 1975.

Palmeos, P. 1962. Karjala Valdai murrak. Tallinn.

Pugh, S. 1987. Structural Aspects of Borrowing in Karelian: the Assimilation of Russian Verbs. Proceedings of the Annual Linguistics Colloquium. Chapel Hill.

1989. The Assimilation of Russian Verbs of Motion in Three Karelian Dialects. The Non-Slavic Languages of the USSR. Linguistic Studies. Ed. Howard I. Aronson. Chicago Linguistic Society and University of Chicago.

1988/89. Russian Verbs of Motion in Veps: a Balto-Finnic Lexical Continuum. Finnisch-Ugrische Mitteilungen, 12/13 Jahrgang. Hamburg.

Rjagoev, V. D. 1977. Tixvinskij govor karel'skogo jazyka. Leningrad.

1980. Obrazcy karel'skoj rexi. Tixvinskij govor sobstvenno karel'skogo dialekta. Leningrad.

Serebrennikov, B. A. 1963. Istori ̌eskaja morfologija permskix jazykov. Moscow.

Virtaranta, P. 1963. Lyydiläisiä tekstejä. I. Suomalais-ugrilaisen Seuran toimituksia 129. Helsinki.

1985. Kriterien zur Klassifizierung der Dialekte des Karelischen. Veröffentlichungen der Societas Uralo-Altaica, Bd. 20: Dialectologia Uralica. Wiesbaden, pp. 117-125.

Zajceva, M. I. 1981. Grammatika vepsskogo jazyka. Leningrad. and M. I. Mullonen 1969. Obrazcy vepsskoj reči. Leningrad. 